Al-Fikra: Jurnal Ilmiah Keislaman, Vol. 5, No. 1, Januari-Juni 2006

\title{
MORALITAS KEPENDIDIKAN: SUATU TELAAH FILSAFAT PENDIDIKAN ISLAM TENTANG ARAH BANGUN PENDIDIKAN ISLAM
}

\author{
Muhmidayeli \\ Fakultas Tarbiyah dan Keguruan UIN Suska Riau
}

\begin{abstract}
Morality of Education: A discussion of Islamic educational philosophy on the direction of Islamic education: The real identity of human beings is morality which should become the ideology of education as a place to make people bumane. The gradual disappearance of moral values in people's daily lives has a significant relationship with the gradual disappearance of the orientation of Islamic education. It therefore becomes a certainty to place the Islamic education as an institution which is not only of a pragmatic, technological and proven dimension but also of an ideal, sacred and moral dimension.
\end{abstract}

Keyword: morality, Islamic education, progresif, transformatif.

\section{Pendahuluan}

Pendidikan dalam gerak sejarahnya selalu mengarah pada progresivitas dan transformativitas kehidupan manusia, sehingga eksistensinya pun mesti pula memuat segala sesuatu yang dibutuhkan manusia, tidak saja yang berdimensi pragmatis, tetapi juga idealis; tidak saja bercorakkan yang profan, tetapi juga yang sakral; tidak saja sarat dengan muatan pengetahuan, tetapi juga moral; untuk kepentingan individu maupun sosial yang mencakup kepentingan kehidupan sekarang ataupun mendatang.

Esensi pendidikan sebagai pengupayaan ke arah perubahan-perubahan perilaku yang lebih "baik", meniscayakan adanya perubahan-perubahan sebagaimana yang diinginkan, sesuai dengan tujuan-tujuan yang telah digariskan oleh suatu lembaga pendidikan sekolah, sebagai bukti nyata adanya aktivitas pendidikan itu sendiri. Perubahan yang dimaksud tentukan bernuansakan progresivitas humanitas, baik konteks hubungan dirinya dengan masyarakat, alam maupun Tuhannya.

Mengingat idealitas manusia menyangkut moralitas, maka pengembangan moralitas tentulah pula mesti menjadi ideologi bagi pendidikan itu sendiri. Penegakan moralitas dalam berbagai kehidupan manusia merupakan bukti nyata bagi adanya aktivitas kependidikan itu sendiri. Mengaburnya nilai-nilai moral dalam kehidupan keseharian manusia tentulah sebagai akibat dari mengaburnya orientasi kependidikan Islam itu sendiri.

Pendidikan sekolah sebagai lembaga yang ditugaskan untuk pengembangan humanitas manusia, pada dasarnya juga mengemban tugas 
pembinaan moral, karena memang manusia diciptakan Tuhan untuk moral, sehingga dalam pendidikan Islam, nilai-nilai moral mestilah menjadi bagian yang integral dalam setiap usaha kependidikannya. Secara struktural-formal tidak mesti hanya sekedar tercantum dalam orientasi dan tujuan pendidikan Islam semata, tetapi hendaklah juga terjalin kelindan dalam setiap denyut nadi aktivitas kependidikan Islam itu sendiri.

Adanya fenomena yang berlangsung pada dunia pendidikan selama ini, menjadikan perilaku moral tertinggal hanya pada tataran idealitas tujuan pendidikannya, sementara pada tataran parxis-metodologis pembelajaran nyaris kurang tersentuh, untuk tidak mengatakan terabaikan atau terlupakan, menunjukkan bahwa pendidikan Islam telah mulai kehilangan jati dirinya, pada hal dalam konteks yang terakhir inilah sesungguhnya upaya kependidikan Islam itu mesti dilangsungkan secara sistematis dan rasional.

Adanya indikasi keterasingan moralitas dan nilai-nilai humanitas dalam lembaga kependidikan sekolah yang ditandai dengan orientasi keilmuan yang semata-mata untuk ilmu an sich dan pemisahan yang tajam antara ilmu pengetahuan dan moral merupakan sesuatu indikasi yang menunjukkan telah bergesernya ideologi dan moralitas pendidikan kepada sesuatu yang bukan esensinya. Robert L. Ebel dalam hal ini menyebutkan, bahwa ada beberapa penyebab terpinggirkannya perhatian kependidikan sekolah terhadap penumbuhkembangan perilaku moral subjek didiknya di antaranya 1.) dalam masyarakat telah terjadi penekanan yang amat kuat terhadap kebebasan individu dari pada tanggungjawab personal, 2.) lebih mementingkan hak-hak sipil daripada kewajiban sipil dan 3) adanya semacam kecenderungan dalam masyarakat bahwa melihat perubahan dan inovasi sebagai sesuatu yang lebih baik dari tradisi dan stabilitas di dalam kehidupan. ${ }^{1}$

Melalui analisis filosofis dengan gaya penalaran deduktif-induktif dan induktif-deduktif, tulisan ini berupaya mencarikan solusi atas persoalan apa dan bagaimana bentuk dan corak moralitas kependidikan dalam Islam yang difokuskan pada permasalahan, idealitas manusia dan kemanusiaan serta hal-hal yang berkenaan dengan masalah esensi pendidikan Islam dan pemanusiaan.

\section{Identitas Manusia}

Karena upaya kependidikan tidak lain adalah suatu upaya pemanusiaan, maka untuk melihat moralitas kependidikan itu mesti diawali dengan mendudukkan makna dan orientasi humanitas agar segala yang akan ditempuh dalam kegiatan kependidikan tidak lari dari esensinya.

${ }^{1}$ Ebel, Robert L., "What are Scholls for", dalam Harvey F. Clarizio et all (Ed)., Contemporary Issues in Educational Psychology, Allyn and Bacon, Inc., Boston, 1977, hlm. 7-8. 
Al-Fikra: Jurnal Ilmiah Keislaman, Vol. 5, No. 1, Januari-Juni 2006

Kata-kata yang dipakai untuk menunjuk hakikat manusia sangat bervariasi, yaitu dengan istilah insān, al-nās dan basyr. Penggunaan istilah-istilah ini menunjuk pada hakikatnya yang berbeda pula.

Kata insān dikaitkan dengan aspek utama kemanusiaan, yaitu kemampuan penalaran yang dengan dayanya ini, manusia mampu mengamati, mencermati, menangkap, mengidentifikasi dan menganalisis berbagai kasus dan kondisi dengan cara menghubungkan fakta-fakta dalam berbagai realitas menuju pengambilan suatu kesimpulan yang akan menjadi pelajaran dan hikmah yang berguna bagi kehidupannya.

Jika dilihat pula dari asal katanya al-uns atau anisa yang berarti jinak memberikan isyarat, bahwa manusia memiliki potensi untuk mudah beradaptasi dan menyesuaikan diri dengan berbagai lingkungan dalam realitas kehidupannya. ${ }^{2}$ Manusia di sini dilihat sebagai makhluk sosial yang ditunjukkan dengan sikap ingin hidup berkelompok dan bermasyarakat, menata kehidupan dalam suatu komunitas, di samping juga ingin bersahabat dengan orang lain di luar diri dan kelompoknya serta berlaku ramah dengan lingkungan dan alam yang mengelilinginya. Manusia dalam konteks ini, adalah makhluk yang memiliki potensi cinta kedamaian dan keharmonisan dalam hidupnya. Oleh karena itu, perselisihan dan pertengkaran di antara manusia adalah semacam penyimpangan natural kemanusiaannya dan atau karena adanya penekanan potensial humanitas lainnya yang saling mendesak, sehingga sifat potensial ini tidak teraktualisasikan dalam tindakan.

Jika dilihat pula dari asal katanya nasiya yang berarti "lupa" menunjukkan bahwa adanya kaitan dengan kesadaran diri manusia dengan aktualisasi fungsionalnya sebagai manusia, karena manusia yang lupa adalah manusia yang lalai, lengah dan kehilangan kesadaran terhadap sesuatu. Kesadaran erat pula kaitannya dengan fungsionalitas akal dan hati manusia dalam memandang suatu realitas. Oleh karena itu, dapat dipahami, bahwa fungsionalitas akal dan hati manusia mesti selalu dipupuk, dibina dan dipelihara agar tidak terjadi kelalaian, kealfaan dan kecerobohan dalam memilih berbagai tingkah laku dalam kehidupannya.

Potensi ruhaniah ini memang merupakan pembeda esensial manusia dari makhluk-makhluk lainnya dan sekaligus menunjuk pada kelebihannya sebagai makhluk yang mulia yang memiliki martabat yang paling tinggi, namun ketika eksistensinya tidak fungsional ia pun dapat merusak tatanan kemanusiaan yang tentu akan menjatuhkan martabatnya sebagai manusia. Dalam surah Bani Israil ayat 70 disebutkan, bahwa manusia berbeda dengan makhluk lainnya karena adanya potensi

2 Bandingkan dengan Abbas Mahmud al-'Aqad, al-Insan fi al-Qur an al-Karim, Dar alQalam, Kairo, 1973, hlm. 156. 
ruhaniah ini, namun jika manusia tidak dapat memfungsikan potensinya secara baik, akan dapat menjatuhkan martabatnya sebagai manusia. ${ }^{3}$

Apabila ditelaah pula kata "basyr" sebagai kata lain yang menunjuk pada hakikat manusia secara harpiah berarti permukaan kulit. Manusia dalam konteks ini dilihat dari aspek lahiriyahnya, yakni manusia sebagai makhluk biologis yang secara esensial tidak berbeda dengan makhlukmakhluk biotik lainnya. Hal ini menunjukkan, bahwa manusia memiliki kesamaan dengan makhluk lainnya yang juga memiliki aspek materi yang terikat dengan hukum-hukum natural.

Adapun kata al-Nas dipakai dalam al-Qur`an untuk menunjuk pada sekelompok orang atau masyarakat yang mempunyai berbagai aktivitas dalam mengembangkan kehidupannya. Dalam pengertian ini, manusia dimaknai sebagai makhluk sosial yang cenderung hidup bermasyarakat. Manusia tidak dapat hidup sendiri. Eksistensinya sangat memerlukan orang lain di luar dirinya. Hal ini menunjukkan bahwa pemaknaannya lebih dekat pada al-uns ataupun anisa.

Kendatipun Islam mengakui bahwa manusia adalah makhluk Allah SWT yang memiliki dua unsur, jasmani dan ruhani yang secara esensial dan eksistensial berbeda dan berdiri sendiri-sendiri, namun Islam pun memandang bahwa dalam pembentukan humanitas manusia, kedua aspek ini saling terkait. Oleh karena itu pengembangan humanitas manusia mestilah juga melalui pengisian potensi-potensi jasmaniah dan ruhaniahnya.

Sebagai makhluk yang termulia, manusia diberi potensi untuk mengembangkan diri dan kemanusiaannya dalam berbagai fungsi dan tanggungjawab kemanusiaannya. Agar potensi-potensi ini menjadi aktual dalam kehidupan perlu dikembangkan dan digiring pada penyempurnaanpenyempurnaan melalui upaya pendidikan. Dengan penciptaan kondisi yang baik dan sempurnalah, menjadikan manusia akan dapat menjalankan

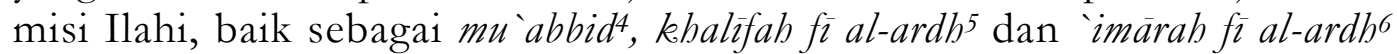
yang kesemuanya berdimensi moral.

Sebagai mu abbid, manusia dalam hal ini dituntut untuk mampu merefleksikan sifat-sifat Tuhan ke dalam dirinya dan menjadikan sifatsifat itu aktual dalam berbagai tindakannya. Pengupayaan menarik sifatsifat Tuhan ini ke dalam dirinya merupakan suatu keniscayaan dalam pembentukan humanitas manusia Muslim. Sifat-sifat Tuhan adalah potret dan lambang kebaikan dan kebajikan yang mesti selalu ditiru dan diupayakan agar ianya menjadi sikap diri menuju aktualisasi diri manusia.

${ }^{3}$ Lihat pula surah al-A raf ayat 179, surah al-Furqan ayat 44 dan surah al-Tin ayat 4 dan 5

${ }^{4}$ Lihat al-Qur`an surah al-Dzariyat ayat 56.

${ }^{5}$ Lihat surah al-Baqarah ayat 30, Shad ayat 26, al-An`am ayat 65 dan Yunus ayat 14.

${ }^{6}$ Lihat surah al-Rum ayat 9 dan Hud ayat 61. 
Al-Fikra: Jurnal Ilmiah Keislaman, Vol. 5, No. 1, Januari-Juni 2006

Kemanusiaan dalam konteks ini mesti selalu diorientasikan pada keyakinan yang dalam (rasa iman) dan aktualisasinya dalam tindakan amal shalih. ${ }^{7}$ Ibadah yang sesungguhnya adalah keterjalinan yang erat antara iman sebagai kesadaran diri manusia atas eksistensi dirinya, alam dan Tuhannya, sedangkan amal perbuatan sebagai aktualisasi dirinya sebagai subjek yang selalu ingin dekat dengan Tuhannya. Pendeknya, kesadaran diri dan aktualisasi diri adalah dua kunci humanitas agar ia berfungsi dan berkembang ke arah kesempurnaan. Dalam realisasinya, kedua unsur humanitas ini membutuhkan instrumen insaniyah, seperti memaksimalkan kerja rasio, hati dan kebebasan diri. Ketiga unsur ini sangat urgen untuk menumbuhkan kesadaran diri dan menjelmakannya dalam tindakan-tindakan senyatanya.

Sebagai khalifah fi al-ardh, manusia bertugas untuk menata dunia sedemikian rupa sehingga dapat menjadikan manusia hidup sejahtera, damai sentosa dan bahagia. Fungsi khalifah ini tidak akan dapat berjalan dengan baik jika manusia belum menjalankan fungsi pertamanya sebagai mu abbid.

Sebagai khalifah Allah SWT di muka bumi, tentulah berarti manusia memegang tugas menjalankan misi Tuhannya di muka bumi, sehingga aneh jika manusia sebagai khalifah Tuhan tidak mengenal Tuhan sebagai "Person" yang diwakilinya. Oleh karena itu, manusia tidak cukup jika hanya mengetahui pengertian tentang siapa Tuhan sebagai "Person" yang diimaninya, tetapi mesti pula mengetahui bagaimana semestinya ia bersikap kepada-Nya serta hal-hal lain yang terkait dengan-Nya. Manusia dalam konteks ini mesti menyadari sepenuhnya tentang hubungan yang erat antara dirinya, Tuhan dan alam sebagai unsur-unsur penting dalam kekhalifahannya.

Sedangkan sebagai imarah fi al-ardh lebih berkonotasi pada pengembang ilmu pengetahuan yang berguna bagi kehidupan manusia, tidak saja di dunia, tetapi juga untuk akhirat.Dalam konteks yang terakhir ini, manusia diperintahkan untuk senantiasa menelaah dan menguak rahasia ciptaan Tuhan dan mengambil hikmah dari padanya, sehingga berbagai kebutuhan kehidupannya dapat terisi dengan baik dan sempurna.

\section{Manusia dan Pendidikan}

Merujuk istilah yang digunakan Islam untuk makna pendidikan, paling tidak terdapat tiga istilah yaitu tarbiyah yang akar katanya rabba, ta'dīb yang akar katanya addaba dan ta'lim yang akar katanya ‘allama. Kata tarbiyah berkonotasi pada aktivitas manusia mengembangkan dan atau menumbuhkan sesuatu secara berangsur-angsur setahap demi setahap

${ }^{7}$ Lihat surah al-Tin ayat 6. 
Al-Fikra: Jurnal Ilmiah Keislaman, Vol. 5, No. 1, Januari-Juni 2006

sampai pada terminal yang sempurna, ${ }^{8}$ istilah ta'dib pada proses pembinaan sikap mental manusia yang erat kaitannya dengan masalah moral dan lebih berorientasi pada pengembangan dan peningkatan martabat manusia, sedangkan ta lim diarahkan pada proses pemberian berbagai ilmu pengetahuan, dari tidak dan atau belum mengetahui sesuatu, maka dengan aktivitas ta 'im menjadikan ia pun mengetahuinya. ${ }^{9}$

Penggunaan ketiga istilah di atas, tentu membawa konsekuensi dan implikasi yang berbeda dalam pelaksanaan dan pengaturan strategi pendidikan itu sendiri. Istilah tarbiyah memberikan aksentuasi kegiatannya pada proses pendidikan yang dilakukan dengan sadar dan terprogram, teratur, sistematis, penuh pertimbangan dan terarah pada suatu tujuan. Sedemikian rupa, sehingga pemakaian istilah ini tentu pula memberikan implikasi pada pendidikan dalam konteks formal yang merupakan usaha sadar bersama setiap komponen kependidikan untuk menciptakan situasi dan kondisi edukatif sedemikian rupa yang dapat memudahkan subjek-subjek didiknya menuju tujuan-tujuan yang telah ditetapkan berdasarkan tahapan-tahapannya. Istilah ta'dib dalam hal ini, memberikan tekanan aktivitasnya pada pembinaan perilaku secara umum, sehingga lebih tepat ditujukan untuk menyebut pendidikan dalam maknanya yang lebih luas, baik dalam bentuk formal, informal maupun yang nonformal. Penggunaan istilah ta'dìb lebih luas dari pada cakupan istilah tarbiyah dan ta lim. Jika istilah ta'lim memberikan tendensi pada proses interaksi edukatif dalam rangka peraihan tujuan-tujuan yang telah ditentukan, istilah tarbiyah lebih pada sebutan pendidikan dalam maknanya yang formal, maka istilah ta'dīb dapat digunakan untuk menunjuk sebutan pendidikan secara umum.

Mengingat tujuan manusia adalah moralitas, maka upaya-upaya kependidikan di sini mestilah juga mengarah pada memoralkan manusia atau memanusiakan manusia. Dengan demikian, upaya kependidikan mestilah ditandai dengan perbaikan-perbaikan dalam moralitas manusia, sehingga kalau tidak ada pembaikan moralitas itu sama artinya tidak ada upaya kependidikan itu sendiri.

Mengingat memanusiakan manusia erat kaitannya dengan menyadarkan manusia akan dirinya yang memang terlahir untuk moral, maka aksentuasi pendidikan mestilah pula mengarah pada upaya menumbuh kembangan kesadaran moral dalam diri manusia sehingga benar-benar aktual dalam kehidupannya. Upaya penyadaran ini erat kaitannya dengan fungsionalisasi rasionalitas manusia yang menjadi pertanda bagi dirinya, terarah sedemikian rupa sehingga benar-benar dapat memecahkan berbagai problem kemanusiaan itu sendiri. Oleh

${ }^{8}$ Raghib al-Isfahani, Mu'jam al-Mufradat Alfaz, al-Qur`an, Ed. Nadim Mar`asyliy, Dar al-Katib al- 'Arabiy, t.tp., t.t., hlm. 189.

${ }^{9}$ Lihat Ibid, hlm.355-356. 
karena itu, pendewasaan intelektual melalui pembinaan berpikir reflektifkritis-kreatif yang akan menumbuhkan konsep diri yang akan membentuk sikap dirinya dalam memandang persoalan-persoalan di berbagai realitas kehidupannya. Upaya penyadaran ini merupakan tugas yang esensial bagi dunia pendidikan, karena memang eksistensinya bersentuhan langsung dengan kemanusiaan itu sendiri. Dengan demikian, penumbuhkembangan berpikir reflektif-kritis-kreatif ini merupakan kata kunci suksesnya suatu pendidikan. Upayanya tentu melalu proses kependidikan yang erat kaitannya dengan pengaturan struktur-struktur psikologis melalui interaksi organisme dengan lingkungan.

\section{Moralitas Sebagai Roh Pendidikan.}

Mengingat manusia adalah makhluk yang diciptakan untuk moral, seperti digambarkan di depan, maka manusia ideal dalam Islam pun selalu bersentuhan dengan persoalan moral. Moralitas secara sederhana dapat dimaknai sebagai suatu perilaku yang baik yang sesuai dengan norma dan nilai-nilai yang diakui oleh suatu masyarakat atau kelompok tertentu. Nilai-nilai moralitas dalam hal ini, selain dapat tampil dalam bentuk norma relijuitas yang telah diatur dan ditetapkan, dapat pula terlahir dari hasil pemikiran subjek-subjek moral terhadap berbagai realita yang ada. Untuk yang terakhir ini memerlukan kematangan berpikir reflektif kreatif

Berfikir reflektif-kreatis adalah semacam corak berpikir yang mengaksentuasikan pemikirannya dalam memandang ke depan setelah menganalisis dan mempertimbangkan plus minus suatu tindakan dengan berbagai konsekuensi yang mungkin akan ditimbulkannya menuju suatu keputusan yang terbaik dari berbagai pilihan yang tersedia. Dalam konteks etika, penelaahan akan konsekuensi tersebut tentu berkenaan dengan memilah dan memilih mana yang paling bermanfaat dan menguntungkan menuju kebaikan dan kebajikan. Dengan demikian, berpikir reflektif-kreatif ini menekankan pencarian moralitas pada kemampuan akal yang dengan cerdas dan terampil menganalisis berbagai kemungkinan konsekuensi dan implikasi dari suatu perilaku moral menuju yang terbaik dan terbajik.

Kematangan berpikir reflektif-kreatif menjadi semakin urgen, terutama bila dihadapkan pada tesis bahwa perilaku potensial manusia menjadi aktual melalui proses penyadaran di satu sisi dan pembiasaan di sisi lainnya seperti yang telah diuraikan di depan.

Perealisasian perilaku moral dalam tindakan-tindakan nyata selalu bersentuhan dengan dorongan kuat yang datang dari dalam diri seseorang untuk bertindak moral, yang biasa disebut dengan kesadaran moral.

Mengingat moralitas memang merupakan perilaku manusia yang dilakukan atas dasar kesadaran yang dalam dari subjek pelakunya, maka moralitas selalu dikaitkan dengan perbuatan-perbuatan tanpa paksaan 
dan desakan dari luar diri manusia. dan oleh karena itu pulalah maka moralitas akan senantiasa bersifat tanpa pamrih dan dorongan dari luar perilaku moral itu sendiri, sehingga perilaku apa pun yang dilakukannya nanti adalah benar-benar dilandasi oleh dasar yang kukuh yang menjadi dirinya konsen terhadap perbuatan itu yang pada akhirnya akan selalu menjelmakannya dalam setiap realisasi dirinya dalam tindakan dan pemikiran.

Pada hakikatnya, dalam diri manusia terdapat sifat-sifat dan unsurunsur ilahiyah berupa potensi-potensi yang mesti dikembangkan dan dijabarkan manusia dalam bentuk perilaku-perilaku nyata. Hal ini karena memang dalam proses kejadiannya manusia ditiupkan ruh dari Tuhannya yang tidak terdapat pada makhluk lainnya. Dengan tugasnya sebagai khalifah fi al-ardh manusia diberi hak untuk mengembangkan dan memelihara sifat-sifat potensial yang berdimensi sifat ilahiyah yang bersemayam dalam dirinya ini agar benar-benar menjadi perilaku-perilaku senyatanya. Manusia dalam hal ini dituntut untuk berpikir kreatif dan inovatif untuk mengembangkan dirinya ke arah perealisasian sifat-sifat Tuhan yang ada dalam dirinya itu dan selalu menjaga dan memelihara sifat-sifat potensial itu dari kehancuran. Berdasarkan inilah maka manusia dituntut untuk tetap selalu tanggap dan tangkas dalam memandang setiap realitas yang ada dalam kehidupannya, sehingga memudahkan dirinya untuk menjadi lebih baik dan sempurna.

Memanusiakan manusia dalam konteks Islam adalah bagaimana menumbuh-kembangkan sifat-sifat hakiki manusia yang telah dianugerahkan Tuhan sebagai lambang bagi kemanusiaannya. Menjadi manusia sejatinya, tentulah mengacu pada pembinaan dan menghidupsuburkan sifat-sifat potensial manusia ini dalam kehidupannya, baik dalam tataran individual dan sosial maupun dalam tataran mu'abbid, khalifah fi al-ardh dan 'imarah fi al-ardh.

Berdasarkan pada tesis di atas, maka pendidikan dalam hal ini tentulah pula sejalan dengan tujuan penciptaan manusia itu sendiri yang menempatkan manusia sebagai mahkluk yang telah diperkaya dengan potensi moralitas. Mengingat nilai kemanusiaan selalu dilihat dari perilaku moral yang ditampilkannya, dan memang misi penciptaan manusia itu sendiri adalah untuk moral, maka. dapat dikatakan, bahwa moralitas adalah juga esensi kemanusiaan. Karena moralitas adalah inti kemanusiaan, maka moralitas mestilah pula dijadikan sebagai sentra bagi upaya pemanusiaan itu sendiri. Pendeknya, menjadikan manusia sebagai manusia adalah juga berarti berupaya menciptakan manusia-manusia yang bermoral.

Dalam Islam, apa yang menjadi tujuan penciptaan manusia, maka itu pulalah yang menjadi cita-cita atau tujuan pendidikannya. Mengingat tujuan penciptaan manusia adalah untuk moral, maka tentu penyempurnaan moralitas 
adalah juga menjadi tujuan dan sekaligus hal yang esensial bagi pendidikan itu sendiri.

Dalam Islam setiap manusia tidak saja diwajibkan untuk menuntut ilmu pengetahuan tanpa batas ${ }^{10}$, tetapi juga mengajarkannya, sehingga ilmunya dapat dinikmati oleh orang-orang lain di luar dirinya. Islam sangat mencela orang yang menyembunyikan ilmunya. Oleh karena itu, pendidikan dalam konteks Islam mestilah dimaknai sebagai segala upaya sadar bersama seluruh komponen pekerja pendidikan yang dilakukan untuk menjadikan subjek didik sebagai manusia utuh atau dengan kata lain, pemanusiaan dan atau pemoralisasian manusia adalah tugas utama pendidikan dalam Islam yang mesti dengan melibatkan berbagai komponen baik dalam struktural maupun fungsional.

Pendidikan sebagai lembaga pembinaan dan penanaman nilai-nilai humanitas merupakan sesuatu hal yang memiliki korelasi positif dengan proses modernisasi dalam kehidupan sosial masyarakat. Pendidikan merupakan sarana penting yang sangat diperlukan dalam proses perubahan sistem sosial, ekonomi dan politik. Oleh karena itu adalah suatu kemestian untuk mengikutkan pendidikan dalam program modernisasi. Pendidikan memiliki kaitan signifikan dengan kualitas suatu masyarakat. Oleh karena itu, pembaharuan-pembaharuan di bidang pendidikan sangat diperlukan agar segala aktivitas yang dilakukan di dalamnya benar-benar dapat menjawab persoalan-persoalan yang berkembang di tengah-tengah masyarakat.

Mengingat Islam memandang bahwa tujuan kemanusiaan sarat nilai dan moral, maka memfungsikan sekolah sebagai usaha aplikatif- kolektif untuk mewujudkan penumbuhkembangan perilaku moral subjek didik hendaklah menjadi orientasi bagi setiap aktivitas kependidikannya. Pendidikan moral mesti berlangsung pada setiap waktu di sekolah, tidak saja dalam kurikulum, tetapi juga dalam interaksi keseharian di sekolah, baik antara siswa dengan guru maupun dengan staf sekolah.

Merujuk firman Allah SWT dalam surah Ali Imran ayat 110; "Kamu adalah sebaik-baik umat yang dilahirkan untuk manusia, menyuruh kepada yang ma`ruf dan mencegah dari yang mungkar dan beriman kepada Allah SWT.', maka ada empat konsep penting yang dicakup di dalamnya, yaitu konsep tentang umat yang baik; aktivitas sejarah; pentingnya kesadaran; dan etika profetik. Umat dapat dikatakan sebagai umat terbaik, tentu jika memenuhi syarat mengerjakan tiga hal yang diungkap dalam ayat, yaitu amar ma ruf, nahi munkar dan beriman kepada Allah SWT. Dalam hal aktivitas sejarah dapat dipahami bahwa manusia bekerja di tengah-tengah manusia dalam membuat sejarah. Nilai-nilai ilahiyah (amar ma`ruf, nahi munkar dan iman) menjadi tumpuan bagi

10 Pemahaman ini dapat dicermati dari hadits Nabi yang berbunyi "thalab al-ilm "ala kull muslim wa muslimah" al-Hadits. 
aktivitas manusia dalam membentuk kesejarahannya, sehingga dapat dipahami bahwa kesadaran dalam konteks Islam selalu berorientasi pada kesadaran ilahiyah yang berbeda dengan kesadaran dalam konteks lainnya. sedemikian rupa, sehingga dapat dikatakan bahwa manusia Muslim dalam melakukan setiap aktivitas kemanusiaannya akan selalu melandasinya dengan orientasi keilahian. Dalam konteks inilah maka banyak filsuf Muslim yang menyebutkan bahwa moralitas manusia pada dasarnya adalah perefleksian sifat-sifat Tuhan ke dalam diri manusia yang menjadikannya sebagai bagian yang tidak terlepaskan dari dirinya. Manusia yang bermoral dalam konteks ini meniscayakan manusia yang berilmu pengetahuan tinggi, jujur dan bertanggungjawab atas diri dan lingkungannya, selalu berkarya, kreatif dan inovatif dan lain sebagainya yang akan menjadikan dirinya mulia dan mesti dimuliakan.

Kecuali itu, iman sebagai realisasi ketauhidan manusia memiliki implikasi dan konsekuensi terhadap penegakan nilai-nilai moral, sehingga penumbuhkembangan perilaku moral manusia pun mesti berkenaaan dengan sejauh mana ia menyadari, bahwa perilaku itu harus ia lakukan. Kesadaran dalam hal ini adalah bukti nyata dari sebuah keyakinan mendalam seseorang atas sesuatu yang dalam bahasa agama disebut dengan iman. Manusia yang menyadari bahwa dirinya, alam jagad raya dan Tuhannya merupakan tiga bagian yang tidak dapat dilupakan begitu saja dalam segala aktivitas kehidupannya, akan selalu mengorientasikan diri dan perilakunya pada keinginan Tuhannya, yakni dengan menjalankan secara ikhlas segala perintah dan menjauhi segala larangan-Nya. Dengan demikian terlihat, bahwa manusia tauhid akan selalu mengorientasikan tindakan-tindakannya baik untuk dirinya, masyarakat maupun alam jagad raya, pada pendekatan diri dengan Penciptanya. Dalam konteks inilah, dapat dikatakan, bahwa manusia tauhid tidak akan pernah melupakan fungsi eksistensialitas dirinya sebagai mu abbid, khalifah Allah SWT fi al-ardh dan immarab fi al-ardh seperti telah diungkap sebelumnya.

Mengingat tauhid merupakan dasar bagi pemunculan sikap tanpa pamrih sebagai identitas yang menunjuk pada moralitas, maka pengupayaan moralitas mestilah pula diawali dengan penanaman nilainilai ketauhidan ini. Hanya dengan cara demikian, maka perilaku moral yang diinginkan oleh Allah SWT sebagai "personal" yang diwakili dapat ditumbuhkembangkan dengan baik.

Manusia tauhid, tidak akan pernah memiliki keinginan apalagi melakukan segala sesuatu yang berseberangan dengan keyakinan tauhid yang ia miliki. Dalam pengertian lain dapat diungkapkan, bahwa manusia tauhid adalah manusia yang dalam segala aktivitasnya selalu menampilkan perilaku moral yang didasari pada nilai-nilai ke-Illahi-an. Allah SWT, tidak hanya sebagai orientasi kehidupanya, tetapi juga sebagai "personal" 
yang diwakilinya di dunia ini, segala tindakannya selalu hendak mengaplikasikan sifat-sifat Tuhan ke dalam dirinya.

Kecuali hal di atas, manusia tauhid pun selalu menginginkan sesuatu yang benar dan senantiasa menegakkan kebenaran, ${ }^{11}$ karena memang tidak akan ada suatu keyakinan ketauhidan tanpa kebenaran. Oleh karena itu pula manusia tauhid adalah manusia-manusia yang bertanggungjawab atas setiap apa yang diucapkan dan yang dilakukannya. Sedemikian rupa sehingga setiap perilakunya selalu disandarkan kepada nama Tuhannya yang Tinggi, karena memang ilmu yang ia peroleh bersifat relatif ${ }^{12}$, tidak seperti ilmu Tuhannya yang mutlak.

Implementasi praktis dalam aktivitas kependidikan, tentunya tidak hanya bergerak pada upaya metodologis-aplikatif akan pentransferan berbagai ilmu pengetahuan dan pembentukan skill an sich yang hakekatnya akan selalu berubah dan berkembang, tetapi juga pada upaya pentransferan nilai-nilai moral ke-Ilahi-an yang bersumber dari alQur'an dan sunah Nabi muhamad SAW. Dalam konteks inilah dikatakan bahwa pendidikan Islam secara kategoris, dapat dilepaskan dari dimensi ke-Ilahi-an sebagai wujud dari ketauhidannya. Apa pun yang dilakukan Islam termasuk persoalan moral mesti selalu terkait dengan Allah SWT.

Mengingat seluruh tingkah laku manusia yang baik ataupun yang buruk yang dilakukan berdasarkan hasil pilihan bebas manusia itu sendiri selalu berkenaan dengan rasionalitas manusia itu sendiri, sedangkan rasionalitas itu selalu bersentuhan dengan kesadaran imani seseorang seperti diuraikan di atas, maka berarti di sini kesadaran merupakan starter point bagi realisasi moral manusia.. Ketika ia memutuskan bahwa suatu perbuatan itu baik dan berguna bagi dirinya, maka ia pun akan memilihnya sebagai suatu perilaku yang mesti dilakukan.

Karena memang kesadaran adalah kata kunci bagi perealisasian moral dalam setiap gerak kehidupan manusia, seperti disinggung di atas, maka implikasinya dalam proses pendidikan moral adalah bahwa setiap upaya yang dilakukan mestilah didasari pada kesadaran subjek pendidik untuk menumbuhkan kesadaran moral pada subjek didiknya agar dengan suka rela dan tanpa paksaan selalu mengarahkan perilakunya pada dimensi moral dan senantiasa atas dasar moral.

Berdasarkan tesis ini pulalah, maka pendidikan agama dan moral yang diarahkan pada pengupayaaan pembinaan kesadaran subjek-subjek didik ini pun dapat dilakukan melalui pendekatan rasional, yaitu suatu pendekatan

11 Dalam konteks ini Allah SWT berfirman dalam surah al-Isra' ayat 36 yang maknanya: "Dan janganlah kamu mengikuti apa yang kamu tidak mempunyai pengetahuan tentangnya. Sesungguhnya pendengaran, penglihatan dan hati, semuanya itu akan diminta pertanggungjawabannya."

12 Dalam surah al-Isra” ayat 85 disebutkan bahwa “... dan tidaklah Kami berikan kamu ilmu kecuali sedikit". 
moral melalui pendidikan dan pembinaan pada pembuatan putusan moral melalui pertimbangan-pertimbangan rasional. Hal ini sangat penting, terutama mengingat kesadaran manusia atas sesuatu selalu berhubungan dengan dapat tidaknya rasio mereka dalam mencerna dan menerima sebuah ajaran sebagai sebuah keyakinan ontologis yang mesti diaktualisasikan dalam tindakan senyatanya dalam kehidupan.

Pendidikan sekolah yang diorientasikan pada nilai-nilai moral dan agama merupakan suatu kebutuhan dan memiliki urgensi bagi penumbuhkembangan perilaku moral senyatanya pada subjek didik. Membangkitkan nilai-nilai moral sebagai motivasi dalam segala aktivitas pendidikan dalam hal ini adalah suatu kemestian. Hal ini tidak saja mengingat bahwa upaya pendidikan selalu mengarah pada perbaikan dan perubahan, tetapi lebih dari itu adalah bahwa pendidikan bersentuhan langsung dengan penumbuh-kembangan moralitas yang merupakan suatu hal yang esensial bagi humanitas manusia. Konsekuensinya dalam pengembangan kemampuan memahami suatu ilmu pengetahuan semestinya pula diiringi dengan kemampuan pengapresiasian nilai-nilai moral yang ada dalam ilmu pengetahuan tersebut. Dalam konteks evaluasi pembelajaran pun selain dievaluasi kemampuan memahami suatu ilmu tidak hanya diukur dari seberapa jauh kemampuan memahami dan menguasai ilmu pengetahuan tertentu, tetapi mesti juga diiringi dengan mengapresiasikan nilai-nilai moral yang ada dalam ilmu tersebut dalam tindakan nyata. Tegasnya saat ini sekolah tidak lagi hanya melahirkan orang pintar yang menguasai disiplin ilmu pengetahaun, tetapi mampu melahirkan orang yang cerdas dan brilian dalam mengapresiasikan nilai-nilai moral dari ilmu pengetahuan yang dimilikinya sehingga teraktualisasi ke dalam perilaku moral yang terpuji.

Sebagai subjek dan objek moral, manusia dituntut memainkan peran proaktifnya dalam rangka menumbuhkembangkan perilaku moral dalam setiap aktivitas kehidupannya, terlebih lagi pada aktivitas pembelajaran di sekolah yang memang memiliki fungsi untuk itu. Untuk lebih meningkatkan fungsi utama sekolah seperti ini, diperlukan adanya upaya peningkatan melalui rekonstruksi metodologis aplikatif pembelajaran dalam upaya menumbuhkembangkan moralitas subjek didik.

Paling tidak upaya peningkatan metodologis aplikatif untuk mengatasi ketidak berdayaan penumbuhkembangan perilaku moral di sekolah mencakup tiga aspek, yaitu 1) memperkuat materi pendidikan agama dalam dimensi substantif dan strategi yang mengacu pada kebutuhan perkembangan subjek 2) penerapan berpikir reflektif etis dalam keseluruhan proses pembelajaran dan 3) menerapkan konsep amar ma`ruf nahi munkar sebagai gerakan kolektif sadar moral, meliputi pembentukan orientasi motivasi nilai dan menumbuhkembangkan kesadaran praktis-sosial terhadap moral.

Ada dua bentuk penataan yang dibutuhkan pada level muatan materi kurikulum, yakni 1) dimensi substantif dan 2) dimensi strategi-operasional Dimaksudkan yang pertama adalah penataan materi-materi pendidikan agama dilihat dari sisi perkembangan yang terjadi pada diri subjek, sosial dan 
Al-Fikra: Jurnal Ilmiah Keislaman, Vol. 5, No. 1, Januari-Juni 2006

problema moral masyarakat dalam upaya penumbuhkembangan perilaku moral subjek dalam kehidupannya. Untuk hal ini misalnya memperhatikan tentang perkembangan psikis subjek seperti intelektual, moral, keagamaan dan psiko-sosial subjek. Demikian pula memperhatikan dinamika moral dan kemanusiaan yang tengah terjadi di dalam masyarakat. Sementara dimaksudkan yang kedua adalah penataan yang rasional dan logis dari setiap elemen kurikulum tertulis setelah mempertimbangkan yang pertama, sehingga kurikulum ini nantinya benar-benar mencerminkan kebutuhan akan penumbuhkembangan moralitas subjek bukan pemberian informasi pengetahuan moralitas kepada subjek.

\section{Kesimpulan.}

Manusia adalah makhluk Allah SAW yang diciptakan untuk penegakan moralitas dan oleh karena itu, pendidikan sekolah sebagai lembaga yang sangat strategis dan potensial dalam menumbuh-kembangkan dan menghidupsuburkan perilaku moral sudah semestikan diarahkan pada pembangunan humanitas yang tidak hanya berdimensi pragmatis, teknologis dan propan tetapi mesti juga bercorakkan yang idealis, sacral dan moral.

Era globalisasi dan informasi yang menjadikan semakin kuatnya hegomoni sistemik berbagai budaya terhadap masyarakat dunia pada umumnya, tidak dapat begitu saja dijadikan dalih afirmatif-pasif bagi kegagalan pendidikan sekolah dalam mewujudkan misi kemanusiaan yang sesungguhnya, penegakan nilai-nilai moral-etis dalam setiap gerak langkah kehidupannya. Pertanyaan penting yang mesti dijawab adalah apa yang mesti dilakukan sekolah agar cita-cita esensialnya dapat terwujud dalam setiap tindakan edukasinya.

Dari apa yang kita temukan terhadap materi pendidikan agama saat ini berdimensikan fiqh oriented, semestinya menjadi psiko-sosial dan humanis oriented, sehingga materi-materi yang kurang mendukung ke arah problema moral yang dihadapi subjek perlu dieliminir, sebaliknya materi yang dibutuhkan subjek didik baik dari segi perkembangan psikis-sosial dan kemanusiaan perlu mendapat perhatian khusus, karena bagaimanapun juga perilaku moral terkait dengan problema psikis, sosial dan kemanusiaan yang tengah dihadapi subjek didik.

\section{Bibliografi}

Abul 'Ainain, 'Ali Khalil, Falsafah al-Tarbiyat al-Islamiyah fi nal-Qur'an al-Karim, Dar al-Fikr al-`Arabiy, 1980.

Al-Abrasyi, Athiyah, Dasar-Dasar Pokok Pendidikan Islam, Bulan Bintang, Jakarta, 1987. 
Al-Fikra: Jurnal Ilmiah Keislaman, Vol. 5, No. 1, Januari-Juni 2006

Al-`Aqad, Abbas Mahmud, al-Insan Filsafat al-Qur`an al-Karim, Dar al-Qalam, Kairo, 1973.

Al-Farabi, "Fuzul Mumtaza`ah fi 'Ilm al-Akhlaq" dalam Majid Fakhry, al-Fikr al-Islam fi al-'Arabiy, juz II, Dar al-Fikr, Beirut, 1980.

al-Hijaziy, Hasan bin 'Ali, Manbaj Tarbiyah Ibn Qayyum, edisi terjemahan, Pustaka, Bandung, 2001.

Al-Isfahani, Raghib, Mu`jam al-Mufradat Alfaz al-Qur`an, Ed. Nadim Mar`asyliy, Dar al-Katib al-`arabiy, t.tp., t.t

--------, al-Dharì a ila Makērim al-Sharìa, Ed. `Abd. Yazid al-Ajami, D àr al-Waf 'à, Kairo, 1987.

-, Taf şîl al-Nash`atayn wa Tah ş ${ }^{-i}$ al-Sa`adatayn, Ed. Abd. Majid Najjar, Beirut, 1988.

.Al-Jamaly, Muhammad Fadil, Nahwa Tarbiyat al-Mukminah, .

........., Falsafat Tarbawiya Mutajaddidah, Dār al-Kasysyāf, Bairut, 1956.

al-Kindi, Rasāil al-Kindi Falsafiya, Ed. Muhammad Abd. Hadi Abu Ridhah, Dār al-Fikr al-'Arabiy, Kairo, 1950, h. 273-280.

Al-Syaibani, Omar Muhammad al-Toumy, Falsafah Pendidikan Islam, Terj. Hasan Langgulung, Bulan Bintang, Jakarta, 1979

Amril M., Etika Islam, Telaah Pemiran Filsafat Moral Raghib al-Isfahani, LSFK2P dan Pustaka Pelajar, Yogyakarta, 2002.

Arifin, M., Ilmu Pendidikan Islam: Suatu Tinjauan Teoritis dan Praktis Berdasarkan Pendekatan Interdisipliner, Bumi Aksara, Jakarta, 1993.

Ashraf, Ali, "Aim and Objectives of Islamic Education", dalam Sajjad Husain dan Ali Ashraf (eds), Crisis Muslim Education", Hodder and Stughton King Abdul Aziz University, Jeddah, 1979.

Ausubel, Theory and Problems of Adolescent Development, Grune and Stratton, New York, 1954, h. 285.

Clarizio, Harvey F., et.all., ContemporaryIssues in Educational Pychology, Allyn and Bacon, inc., Boston, 1977.

Dt. Mangkudum, N.A.Rsyid, Manusia dalam Konsep Islam, Karya Indah, Jakarta, 1983.

Ebel, Robert L., "What are Schools for" dalam Harvey F. Clarizio et all (ed), Contemporary Issues in Educational Psychology, llyn and Bacon, Inc, Boston, 1977.

Gander dan Gardiner, Child and Adolescent Development, Little Brown and Company, Boston, 1981. 
Al-Fikra: Jurnal Ilmiah Keislaman, Vol. 5, No. 1, Januari-Juni 2006

Hurlock, Child Depelopment, Mc. Graw-Hill Book Company, Inc, New York, 1956.

Ibn Miskawaih, Tahzît al-Akhtaq, ed. Syekh Hasan Tamir, Mahdawi, Bairut, $1398 \mathrm{H}$.

-, Tahzîb al-Akhtaq, Edisi Indonesia, terjemahan Helmi Hidayat, Mizan, Bandung, 1994.

-------, al-Fawz al-A sghar, D ār Maktabah al-Hāyah, Bairut, tt.

---------, Tajārib al-Umām, I, D ār al-Fikr, Bairut, tt.

, Kitāb al-sa'àdah fí Falsafah al-Akhtã, Matba'ah al-'Arabiyah, Mesir, 1928.

" Kitāb al-'Aql wa al-Ma'qūl", dalam Arkoun, "Notes et Document; Miskawaih de L'intelelect et de L'inteligible", Arabica, 16.

Ibn Sina, "Ris āla 'Ilm al-Akhlāq" dalam Majid Fakhry, al-Fiker alAkblaq fi al- Arabiy, Juz II, al-Ahliyah, Bairut, 1979.

......... "Ris āla fĩ al-Nafs", dalam Majid Fakhry, Ethica Theories in Islam, E.J. Brill, Leiden, 1991.

Irwin, D. Micheille, "Moral Educatin" dalam Harnold E. Midzel, Encyclophedia of Educational Risearch, Vol. 3., The Free Press, Mecmillan Publishing, Co. Inc., New York, 1986.

Fazlurrahman, Islam dan Modernitas tentang Transformasi Intelektual, Pustaka , Bandung, 1985.

J.J.Rousseau, Discours sur L'origine et Les Fondements de L'inégalité Parmi Les Hommes, Presentation par Bertan de Jouvenel, Gallimard, 1965

Kuntowijoyo, Paradigma Islam; Interperetasi Untuk Aksi,Mizan, Bandung, 1993.

........., "Ilmu Sosial Profetik: Etika Pengembangan Ilmu-Ilmu Sosial", dalam al-Jami ah, No. 61/1998.

Langgulung, Hasan, Manusia dan Pendidikan; Suatu Analisis Psikologi dan Pendidikan, al-Husn Zikra, Jakarta, 1995.

Muhammad, Abu Bakar, Membangun Manusia Seutubnya Menurut al-Qur'an, alIkhlas, Surabaya, 1987.

Muhni, Juritna A. Imam., Moral dan Religi Menurut Emile Durkheim dan Hendri Bergson, Kanisius, Yogyakarta, 1994, h. 35-36.

Nancy Davis (Ann), "Contemporary Deontology" dalam dalam Piter Singer (ed), A Compation to Ethics, Black-Well, New York, 1992. 
Al-Fikra: Jurnal Ilmiah Keislaman, Vol. 5, No. 1, Januari-Juni 2006

Praenkel, Jack R., How to Teach about Values: An Analytic Approach, Anglewood Cliff, New Jersey, 1977.

Pratt, Curriculum Design and Development, Harcount Brace Jovanorich, Publishers, London,1980.

Ross, Daniel., "Anthony Giddens” dalam Peter Beilharz (ed), Social Theory: $A$ Guide to Central Thinkers, Allen and Unwin Pty Ltd, 1991.

Shihab, Quraish M, Wawasan al-Qur`an, Mizan, Jakarta, 1999.

Sutton dan Smith, Child Psykology, Apleton Century Croffts, New York, 1973.

Taba, Curriculum Development Theory and Practice, Harcout, Brace and World, Inc, New York, 1962.

Taylor, Paul W., "Introduction: What is Morality" dalam Paul W. Taylor (ed), Problems of Moral Philosophy: An Introduction to Ethics, Dickenson Publishing Company, Inc., California, 1967. 